\title{
Solar damage in intertidal corals
}

\author{
B. E. Brown ${ }^{1}$, R. P. Dunne ${ }^{1}$, T. P. Scoffin ${ }^{2}$, M. D. A. Le Tissier ${ }^{1}$ \\ ${ }^{1}$ Department of Marine Sciences and Coastal Management, University of Newcastle upon Tyne, \\ Newcastle upon Tyne NE1 7RU, United Kingdom \\ ${ }^{2}$ Department of Geology and Geophysics, University of Edinburgh, Edinburgh EH9 3JW, United Kingdom
}

\begin{abstract}
Solar irradiation has been cited as a possible cause of bleaching in corals, either acting alone or in conjunction with other environmental factors. However, evidence of a solar involvement in naturally occurring bleaching is still largely conjectural. We have recorded a particular type of naturally occurring bleaching damage at intertidal sites at Phuket, Thailand for a number of years which has a strong directional component. Use of tidal data, sun track analysis, and solar irradiance measurements have enabled us to show that this bleaching directly corresponds to sun altitude and azimuth. Our work has shown that for the massive coral Goniastrea aspera, bleaching is induced during periods of subaerial exposure with high sun altitude and irradiance. Furthermore, on-site measurements of solar irradiance mitigate against the biologically damaging effect of shorter wavelength ultraviolet radiation (UVR) as a major causative factor. Desiccation, heating, or photochemical reactions by photosynthetically active radiation (PAR) $(400$ to $700 \mathrm{~nm})$ remain possible candidates for further investigation
\end{abstract}

KEY WORDS: Coral · Bleaching $\cdot$ Solar radiation $\cdot$ UVR $\cdot$ PAR

\section{INTRODUCTION}

Over the last decade there has been an increasing incidence of reports on coral bleaching (defined as a reduction in the number of zooxanthellae in coral tissues and/or a decrease in the chlorophyll pigment they contain) at sites around the world. Factors responsible for bleaching are not well understood though recent reviews (Glynn 1984, 1991, 1993, Williams \& BunkleyWilliams 1990, Brown \& Ogden 1993) have highlighted the apparent correlation with locally elevated seawater temperatures. These authors acknowledge, however, that increased seawater temperature is not the only environmental factor which may be implicated in recent coral bleaching events.

Solar radiation has also been cited as a factor causing bleaching, both in naturally occurring events in the field and in manipulative field and laboratory experiments where bleaching has been artificially induced. In most cases the work has attempted to identify the damaging wavelengths [e.g. ultraviolet radiation (UVR, 280 to $400 \mathrm{~nm}$ ) or photosynthetically active radiation (PAR, 400 to $700 \mathrm{~nm}$ )], often unsuccessfully, and to define whether the bleaching response is a product of reduced numbers of zooxanthellae in the host ani- mal, and/or a reduced chlorophyll pigment concentration in the zooxanthellae themselves.

In the case of naturally occurring coral bleaching. Fisk \& Done (1985) and Harriott (1985) reported shallow water bleaching of corals on the Great Barrier Reef during 1982. They suggested a link to a period of high solar irradiance and conjectured that UVR may be implicated.

Experimental inducement of coral bleaching in the field has involved transplantation of corals from deeper to shallower water where they have been exposed to higher than normal solar irradiance (and an altered spectral composition). Hoegh-Guldberg \& Smith (1989) recorded bleaching in shallow water colonies of Stylophora pistillata and Seriatopora hystrix moved from $6 \mathrm{~m}$ to $12 \mathrm{~cm}$ depth. In deeper water, specimens of Plerogyra sinuosa transplanted from $25 \mathrm{~m}$ to $5 \mathrm{~m}$ died within $30 \mathrm{~d}$ (Vareschi \& Fricke 1986), whilst Montastrea annularis moved from $24 \mathrm{~m}$ to $12 \mathrm{~m}$ bleached after $21 \mathrm{~d}$ (Gleason \& Wellington 1993). In both cases UVR (280 to $400 \mathrm{~nm}$ ) was cited as the cause, but lack of adequate controls prohibits this conclusion (Dunne in press). Similar work by Kinzie (1993) demonstrated reductions in areal chlorophyll concentrations in Montipora verrucosa as a result of elevated solar UV ( 280 to $380 \mathrm{~nm}$ ) irradiance. 
In laboratory experiments, Siebeck (1988) recorded rapid tissue death in 2 species of corals, Favita pallida and F complanata, following exposure to artificial UVR (275 to $320 \mathrm{~nm}$ ), but this was only at wavelengths and energies which far exceed the natural solar spectrum. Additional relevant laboratory studies have involved other zooxanthellae symbioses being exposed to elevated natural and artificial solar radiation. In the case of the anemone Aiptasia pallida (Lesser 1989, Lesser \& Shick 1989) and the zooanthid Palythoa caribaeorum (Lesser et al. 1990) elevated PAR (400 to $700 \mathrm{~nm}$ ) consistently induced bleaching-type responses involving reduced zooxanthellae chlorophyll content. This contrasted with elevated UVR (280 to $400 \mathrm{~nm}$ ) where any bleaching type response was limited only to a reduction in chlorophyll fluorescence in Aiptasia pallida using flow cytometry (Lesser 1989. Lesser \& Shick 1989)

In this paper we record natural occurrences of a localised and highly directional form of bleaching in intertidal massive corals at Phuket, Thailand. In March 1990 first note was made of the extensive appearance of bleached areas (lesions) on the western surfaces of massive reef flat corals, namely Goniastrea aspera, G. pectinata, $G$. favulus, G. retiformis, Porites lutea, Coeloseris mayeri and Platygyra sinensis. Subsequent studies in July 1991, March, July and November 1992, and March 1993 on the faviid coral $G$. aspera have enabled us to show that this form of bleaching directly corresponds to sun altitude and azimuth and is induced during periods of subaerial exposure with high sun altitude and irradiance. The contribution of specific wavelength effects and the irradiance levels associated with this type of bleaching are also considered in this paper.

\section{MATERIALS AND METHODS}

Study sites and measurement of lesions. The study was based on intertidal reef flats along the southeast coast of Phuket, Thailand (Fig. 1). These reef flats are up to $200 \mathrm{~m}$ wide with a shallow gradient from shore seawards (ca $10 \mathrm{~cm}$ per $100 \mathrm{~m}$ ) and are characterised by moderate cover ( 40 to $70 \%$ ) of live corals, dominated by massive species of the genera Porites and Goniastrea. Detailed descriptions of the location are given in Ditlev (1978), Brown \& Holley (1982) and Scoffin et al. (1992). Coral community studies have been

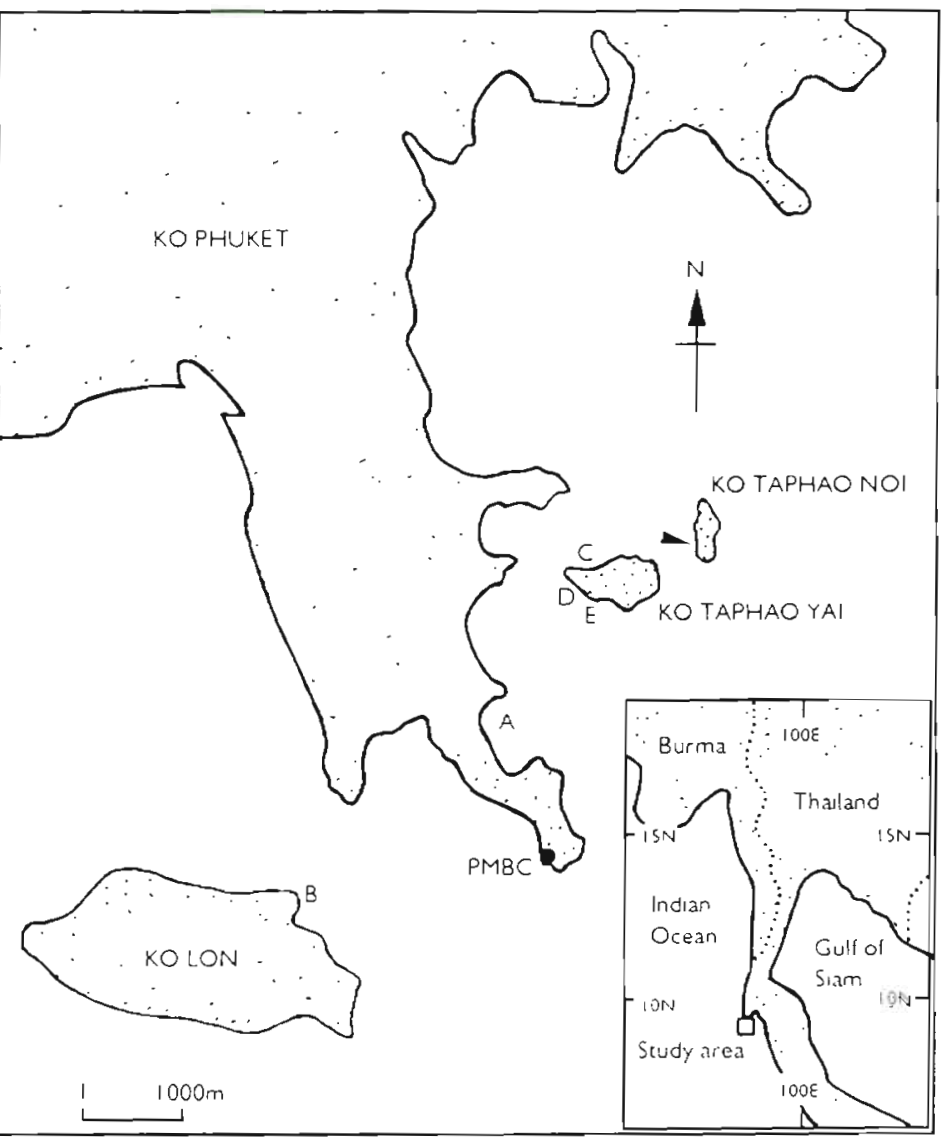

Fig. 1. Location of Ko Phuket, Thailand, showing study sites ( $A$ to E), tide tation (shown by arrowhead) and Phuket Marine Biological Centre (PMBC)

conducted at this site over a period of 14 yr (1979 to 1993) by Brown et al $(1990,1993)$. Throughout this period, site visits (generally twice a year) have provided data on the intertidal reefs during the 2 main climate seasons, the wet and cool SW monsoon (May to October), and the hot dry NE monsoon (November to Aprii).

Quantitative evidence of solar lesions was collected from hemispherical colonies of Goniastrea aspera, where the circular/elliptical nature of the lesions permitted accurate measurement of orientation. Detailed monitoring of lesions on coral colonies was carried out

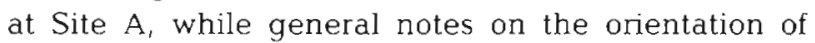
lesions were additionally made at Sites B, C, D \& E to provide comparative information on corals from locations with differently oriented coastlines (Fig. 1). The orientation of the centres of lesions were recorded in all cases for compass bearing, and at Site $A$ also for elevation. Elevation (the angle between the plane of the earth's surface and a line normal to the lesion centre) was measured from the horizontal with an inclinometer $\left( \pm 5^{\circ}\right)$ and bearing with a magnetic compass $\left( \pm 5^{\circ}\right)$. 
In December 1992 a $220 \mathrm{~m}^{2}$ rectangular area of reef flat was surveyed at Site $A$ and the heights of the tops of 130 hemispherical colonies within this area were recorded to a resolution of $1 \mathrm{~mm}( \pm 1 \mathrm{~mm})$ using optical levelling techniques (Wild NA28 automatic level). In March 1993, measurements of colony diameter and lesion size were made for the 37 colonies bearing fresh lesions in the surveyed area. Colony diameter was measured using callipers and lesion diameter was measured in 2 directions, north-south and east-west, with a ruler to correspond with the largest and smallest diameters of elliptical lesions respectively; values were recorded to the nearest $0.5 \mathrm{~cm}$.

Duration and frequency of subaerial exposure and sun altitude and azimuth. At Site $A$ a tidal datum was established from timed on-site tidal observations and used in conjunction with daily tidal curves to establish the time and duration of subaerial exposure of the colonies. (For the purpose of this paper we use the term 'subaerial' exposure to mean that period of time in a tidal cycle during which a coral colony is exposed to the air over the whole or a majority of its surface. The lower portion of some colonies may remain in water which is 'pooled' on the reef flat.) Tidal curves were computed using the Admiralty Simplified Harmonic method of tidal prediction (Hydrographic Office NP159A Version 2.0) for microcomputers and the 1992 harmonic constants for Ko Taphao Noi tidal station $\left(7^{\circ} 50^{\prime} \mathrm{N}, 98^{\circ} 25.5^{\prime} \mathrm{E}\right) 1.5 \mathrm{~km}$ from Site A. From the times of emergence and resubmergence of the colonies, maximum sun altitude and corresponding azimuth for each period of subaerial exposure was determined with an altitude/azimuth plotting program (Her Majesty's Nautical Almanac Office, Royal Greenwich Observatory, UK).

Meteorological data of daily sunshine hours for Phuket Airport (1981 to 1992), $32 \mathrm{~km}$ to the north, was obtained from the Meteorological Department, Bangkok, and mean sea level information for Ko Taphao Noi (1940 to 1991) from the Permanent Service for Mean Sea Level (Proudman Oceanographic Laboratory, UK).

Measurements of solar irradiance. Solar irradiance was recorded continuously at Phuket Marine Biological Centre (reading every $1 \mathrm{~min}$; averaged and recorded every $10 \mathrm{~min}$ ) across 4 wavebands from December 1992 to March 1993 using a variety of sensors: (1) short wavelength UVR (Macam Photometrics Ltd PD105B-Cos detector); peak wavelength $313 \pm$ $2 \mathrm{~nm}$, bandwidth $26 \pm 1 \mathrm{~nm}, 50 \%$ response bandwidth 303 to $328 \mathrm{~nm}, 2 \pi$ collector cosine-corrected $( \pm 3 \%$ to $72^{\circ}$ ); (2) longer wavelength UVR (Macam Photometrics Ltd PD105A-Cos detector) peak $373 \pm 2 \mathrm{~nm}$, bandwidth $31 \pm 1 \mathrm{~nm}, 50 \%$ response bandwidth 352 to $383 \mathrm{~nm}$, $2 \pi$ collector cosine-corrected $\left( \pm 2.5 \%\right.$ to $\left.80^{\circ}\right)$; (3) visi- ble/near infrared (Macam Photometrics Ltd SD101RVCos detector), bandwidth 390 to $1100 \mathrm{~nm}, 50 \%$ response bandwidth 415 to $1000 \mathrm{~nm}, 2 \pi$ collector cosine-corrected $\left(+1.2-10 \%\right.$ to $\left.70^{\circ}\right) ;$ (4) 350 to $2500 \mathrm{~nm}$ Delta T Devices Ltd TSM tube solarimeter (Szeicz et al 1964, Green \& Deuchar 1985). All sensors were mounted horizontally.

Absolute measurements of solar irradiance were made for typical clear sky conditions at Phuket Marine Biological Centre (4 March 1993) using a Macam Photometrics SR 9910 double-grating spectroradiometer fitted with a teflon cosine-corrected $2 \pi$ collector (bandwidth $2 \mathrm{~nm}$, stray light $<2 \times 10^{-8}$, wavelength accuracy $\pm 0.5 \mathrm{~nm})$. The spectroradiometer was calibrated before use at $29^{\circ} \mathrm{C}$ (ambient) against deuterium and tungsten lamps. Scans were from 280 to $700 \mathrm{~nm}$, step length $2 \mathrm{~nm}$. Measurements were taken for 3 differently oriented surfaces: (1) for a 'horizontal surface' the plane of the cosine collector was oriented parallel to the earth's surface; (2) for an 'inclined irradiated surface', at $50^{\circ}$ elevation to the horizontal (zenith angle $40^{\circ}$ ) and $254^{\circ}$ compass bearing, corresponding to the orientation of the centre of a typical lesion (i.e. 'irradiated' in the afternoon); and (3) for an 'inclined shaded surface' the cosine collector was again at $50^{\circ}$ elevation but on the reciprocal (east facing) bearing of $74^{\circ}$ (i.e. 'shaded' in the afternoon).

Sea surface temperature. Sea surface temperature (SST) was obtained from 3 independent sources. (1) Hourly temperatures were measured using a 2Kohm thermistor located $0.5 \mathrm{~m}$ below chart datum $0.5 \mathrm{~km}$ southeast of Site A. The thermistor was calibrated against a NAMAS calibrated precision mercury-in-glass thermometer to an absolute accuracy of $\pm 0.06^{\circ} \mathrm{C}$. (2) Long term monthly 'normal' SST (1951 to 1980) were obtained from the Global Ocean Surface Temperature Atlas (GOSTA 1990) and 1993 monthly means from the MOHSST4 data set (United Kingdom Meteorological Office). In both cases values were extracted for the 5 degree latitude $\times$ longitude area for the sea around Phuket. (3) Weekly records were obtained from Phuket Marine Biological Centre (PMBC), recorded at a depth of $1 \mathrm{~m}$ at 09:00 $\mathrm{h}$ using a Mini STD Model SD202 (absolute accuracy unknown).

Statistical analysis. Linear statistical analysis was carried out using the protocols in Fry (1993). Data for monthly mean sea level and for monthly mean sun hours were both homoscedastic (Hartley's $F_{\max }$ ) but some months had slightly non-normal distributions. In both cases, therefore, non-parametric multiple Mann Whitney $U$-tests were used for statistical comparisons. Circular and spherical statistics for sun direction and lesion orientation follow the techniques in Batschelet (1981), Zar (1984) and Mardia (1972). 


\section{RESULTS}

\section{Measurement and morphology of solar lesions}

The extensive appearance of westerly facing lesions on a variety of intertidal massive corals was first noted in March 1990. The shape of these lesions related to the gross morphology of individual colonies; e.g. on the western sides of hemispherical colonies the lesions were circular to elliptical (Fig. 2a, b), whereas on annular colonies they were elongate. Immediately following bleaching, the coral tissue within lesions remained viable, though in many cases necrotic areas in the centre of the lesion were apparent within 2 to $3 \mathrm{~d}$. In the longer term ( 1 to $2 \mathrm{wk}$ ) many lesions were covered with a thin coat of sediment which persisted thereafter (for the purpose of this paper these sediment-coated dead areas are referred to as lesion scars). Coincidental with the appearance of fresh lesions in hitherto undamaged colonies, previously affected colonies also showed further lesion development around the perimeter of lesion scars (Fig. 2c, d). This partial mor-
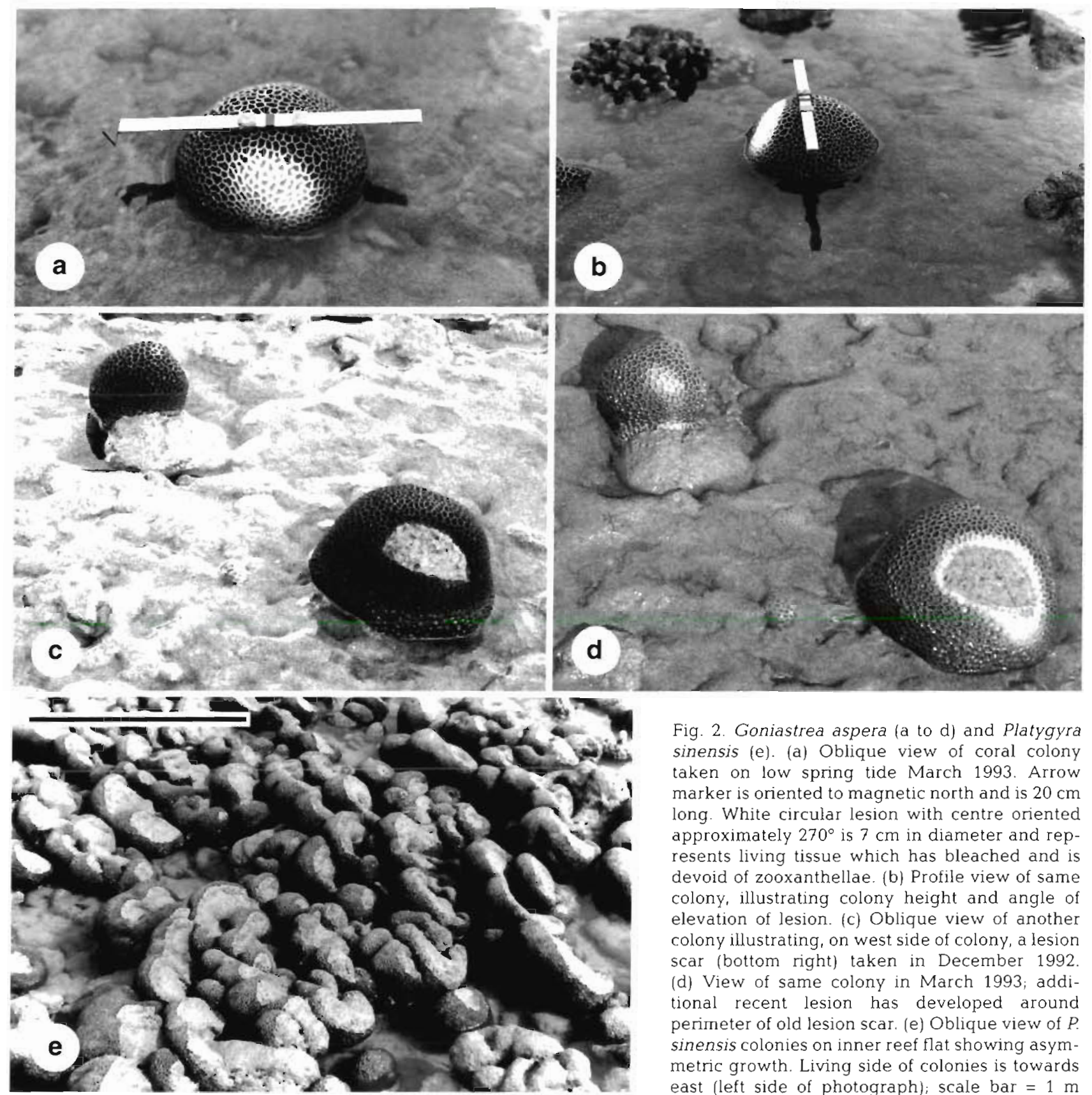

Fig. 2. Goniastrea aspera (a to d) and Platygyra sinensis (e). (a) Oblique view of coral colony taken on low spring tide March 1993. Arrow marker is oriented to magnetic north and is $20 \mathrm{~cm}$ long. White circular lesion with centre oriented approximately $270^{\circ}$ is $7 \mathrm{~cm}$ in diameter and represents living tissue which has bleached and is devoid of zooxanthellae. (b) Profile view of same colony, illustrating colony height and angle of elevation of lesion. (c) Oblique view of another colony illustrating, on west side of colony, a lesion scar (bottom right) taken in December 1992 (d) View of same colony in March 1993; additional recent lesion has developed around perimeter of old lesion scar. (e) Oblique view of $P$. sinensis colonies on inner reef flat showing asymmetric growth. Living side of colonies is towards east (left side of photograph); scale bar $=1 \mathrm{~m}$ 


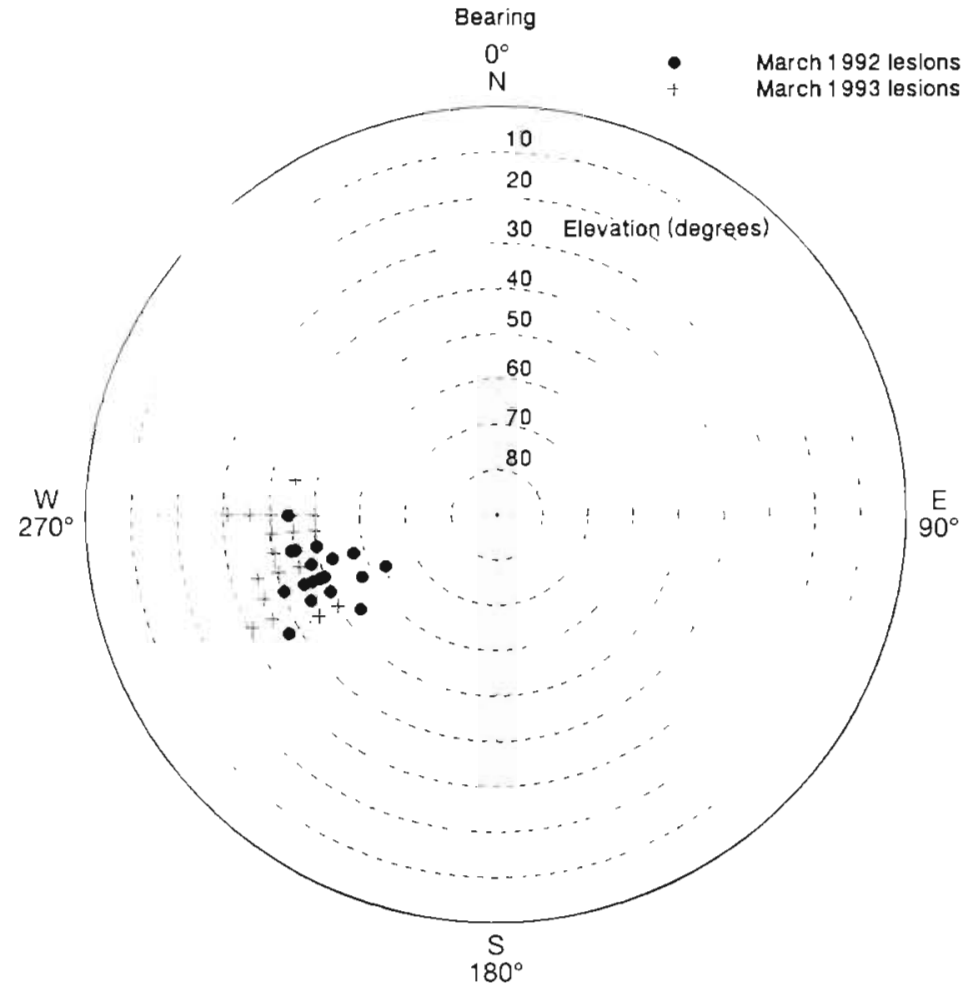

Fig. 3. Goniastrea aspera. Polar plot of the centre of lesions recorded from 20 coral colonies in March 1992 and 50 lesions in March 1993. Note: some symbols indicate more than 1 lesion where there was identical orientation

tality leads to a strikingly asymmetrical growth, with a high proportion of massive colonies developing inclined planar dead western sides and actively growing convex eastern sides (Fig, 2e).
In March 1992 and thereafter, observations on lesions were restricted to small ( 7 to $30 \mathrm{~cm}$ diameter) hemispherical colonies of Goniastrea aspera. Lesions on these colonies consisted of a circular/elliptical area of white surface against the otherwise uniformly light brown natural colour of the colonies. Measurement of the orientation of the centre of fresh lesions on 20 colonies from Site A on 8 March 1992 gave compass bearings of $235^{\circ}$ to $270^{\circ}$ (mean angle $251^{\circ}$ ) and elevations between $37^{\circ}$ and $64^{\circ}$ (mean $49^{\circ}$ ). These lesions had not been present on a previous site visit in July 1991. Further measurements of fresh lesions which appeared on 7 March 1993 (and which had not been present in December 1992) on 50 different colonies gave bearing and elevation values of $240^{\circ}$ to $280^{\circ}$ (mean $261^{\circ}$ ) and $30^{\circ}$ to $50^{\circ}$ (mean $42^{\circ}$ ) respectively (Fig. 3, Table 1). Lesions and lesion scars recorded at Sites B, C, D \& E had mean orientations of $272^{\circ}, 246^{\circ}, 266^{\circ}$ and $274^{\circ}$ respectively. In all cases the length of the mean vector for bearing and elevation (where measured) indicated a highly directional unimodal clustering. The spherical variance for the March 1992 and March 1993 lesions at Site $A$ was also very small $\left(S^{*}=\right.$ 0.0097 in $1992,0.0132$ in 1993). In 37 colonies at Site $\mathrm{A}$ where dimensions of both colony and lesions were measured, colony diameter ranged from 7 to $22 \mathrm{~cm}$ while diameters of circular/elliptical lesions (min. $\times$ max. diameter) varied from $1.5 \times 2 \mathrm{~cm}$ to $7 \times$

Table 1. Goniastrea aspera. Circular and spherical statistical parameters for lesions on coral colonies. FL: fresh lesions; OL: old lesion scars. Elevation parameters for Sites B to E were not measured

\begin{tabular}{|c|c|c|c|c|c|c|}
\hline $\begin{array}{r}\text { Site: } \\
\text { Date: } \\
\text { Nature of lesion/scar: } \\
\mathrm{n}:\end{array}$ & $\begin{array}{c}\text { A } \\
8 \text { Mar } 1992 \\
\text { FL } \\
20\end{array}$ & $\begin{array}{c}\text { A } \\
7 \text { Mar } 1993 \\
\text { FL } \\
50\end{array}$ & $\begin{array}{c}\text { B } \\
\text { Jul } 1992 \\
\text { OI } \\
79\end{array}$ & $\begin{array}{c}\text { C } \\
\text { Mar } 1993 \\
\text { FL, OL } \\
15\end{array}$ & $\begin{array}{c}\text { D } \\
\text { Mar } 1993 \\
\text { FL, OL } \\
6\end{array}$ & $\begin{array}{c}\mathrm{E} \\
\text { Mar } 1993 \\
\text { FL, OL } \\
7\end{array}$ \\
\hline \multicolumn{7}{|l|}{ Bearing } \\
\hline Mean angle, $\Phi$ & $251^{\circ}$ & $261^{\circ}$ & $272^{\circ}$ & $246^{\circ}$ & $266^{\circ}$ & $274^{\circ}$ \\
\hline Length of mean vector ${ }^{\circ}, I$ & 0.99 & 0.984 & 0.983 & 0.974 & 0.969 & 0.987 \\
\hline Angular deviation ${ }^{b}, \pm S$ & $7.66^{\circ}$ & $10.27^{\circ}$ & $10.72^{\circ}$ & $13.07^{\circ}$ & $14.22^{\circ}$ & $9.16^{\circ}$ \\
\hline \multicolumn{7}{|l|}{ Elevation } \\
\hline Mean angle, $\Phi$ & $49^{\circ}$ & $42^{\circ}$ & & & & \\
\hline Length of mean vector ${ }^{a}, r$ & 0.994 & 0.996 & & & & \\
\hline Angular deviation ${ }^{b}, \pm S$ & $6.16^{\circ}$ & $5.33^{\circ}$ & & & & \\
\hline Spherical variance ${ }^{\circ}, S^{*}$ & 0.0097 & 0.0132 & & & & \\
\hline \multicolumn{7}{|c|}{$\begin{array}{l}\text { a Length of the mean vector acts as a measure of concentration, thus for a random distribution about } 360^{\circ} r=0 \text {, and when all } \\
\text { angles are the same } r=1\end{array}$} \\
\hline
\end{tabular}




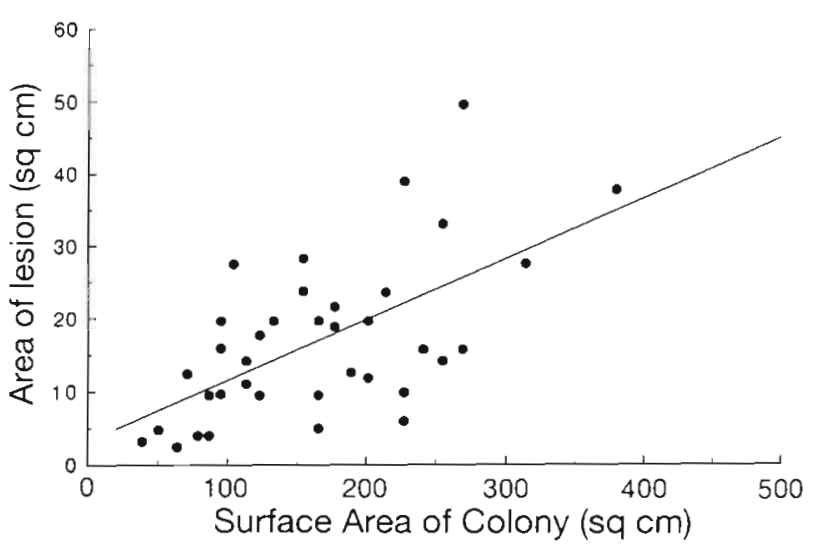

Fig. 4. Goniastrea aspera. Regression plot of the colony surface area and lesion area for hemispherical colonies bearing fresh lesion damage at Site A on 7 March 1993. $(y=0.083 x+$ $\left.3.21, r^{2}=0.37, n=37, p<0.001\right)$

$9 \mathrm{~cm}$. Lesion area and colony surface area were positively correlated ( $p<0.001)$ (Fig. 4). Although we have observed some lesion formation at other times of the year, both in the field and in photographic records of lesion scars, we have consistently recorded the greatest incidence and severity on a seasonal basis in late February and March.

\section{Subaerial exposure and sun track analysis}

The height of Goniastrea aspera colonies showing new lesion damage on 8 March 1992 fell within a narrow vertical range of less than $10 \mathrm{~cm}$ of each other. Analysis of predicted tidal curves permitted a daily time pattern of subaerial exposure to be constructed from July 1991 (when these lesions had not been present) to March 1992. The tidal form experienced at Phuket is semi-diurnal having a range of $0.6 \mathrm{~m}$ (neap tides) to $3.1 \mathrm{~m}$ (spring tides), and with relatively little variation in range between successive high and low waters (for example of tidal curve see Ditlev 1978). Because of this pattern, the typical $14 \mathrm{~d}$ cyclical increase and decrease in range, coupled with the tidal period, results in the low water of the spring tides consistently falling either early in the morning or in the afternoon. It is only on low spring tides that the intertidal coral reefs at Phuket are subaerially exposed. The tidal pattern results in longer periods of subaerial exposure of Goniastrea aspera colonies during afternoon low tides than those in the morning (Fig. 5a). There is also a seasonal component to subaerial exposure with total exposure time greatest on afternoon tides in February-April, and for morning tides in January-February. This seasonal component is partly a factor of the timing of the tide and partly due to the marked seasonal depression of mean sea level by up to $20 \mathrm{~cm}$ at this time of year (Fig, 5b).

The orientation of lesions on the western side of the coral colonies together with the pattern of much greater subaerial exposure on the afternoon tides alone suggested that bleaching damage is linked to the coral's exposure to direct solar irradiance. Computation of the sun's position during periods of subaerial exposure between July 1991 and the end of February 1992 showed that both the frequency of subaerial exposure and the maximum sun altitude are greater during afternoon periods than in the mornings (Fig. 6a). Comparison of Figs. 3 \& 6a intuitively reveals a good azimuth match between the position of the
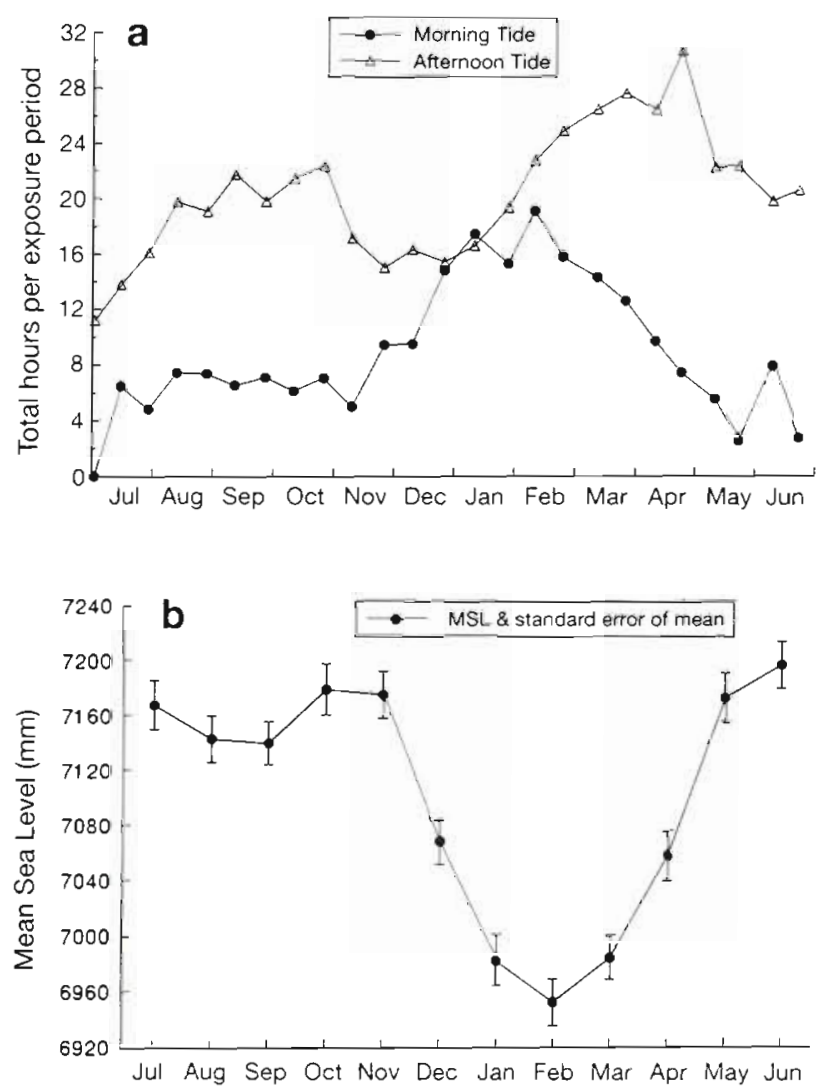

Fig. 5. (a) Seasonal variation in daylight aerial exposure at Site $A\left(7^{\circ} 48.8^{\prime} N, 98^{\circ} 24.5^{\prime} \mathrm{E}\right)$. Hours of exposure have been summed for each group of successive days of low spring tides. Groups are at approximately $14 \mathrm{~d}$ intervals and are interspersed by periods of neap tides when the reef is submerged at all tidal heights. (b) Seasonal variation in mean sea level (MSL) at Ko Taphao Noi tidal station (1940 to 1991). Plotted from data obtained from the Permanent Service for Mean Sea Level (Proudman Oceanographic Laboratory). The large seasonal depression in January to April reflects barometric pressure and offshore wind effects of the NE monsoon. The lowering in MSL results in the lowest low spring tides of each year in the month of February. $\mathrm{n}=51$ 


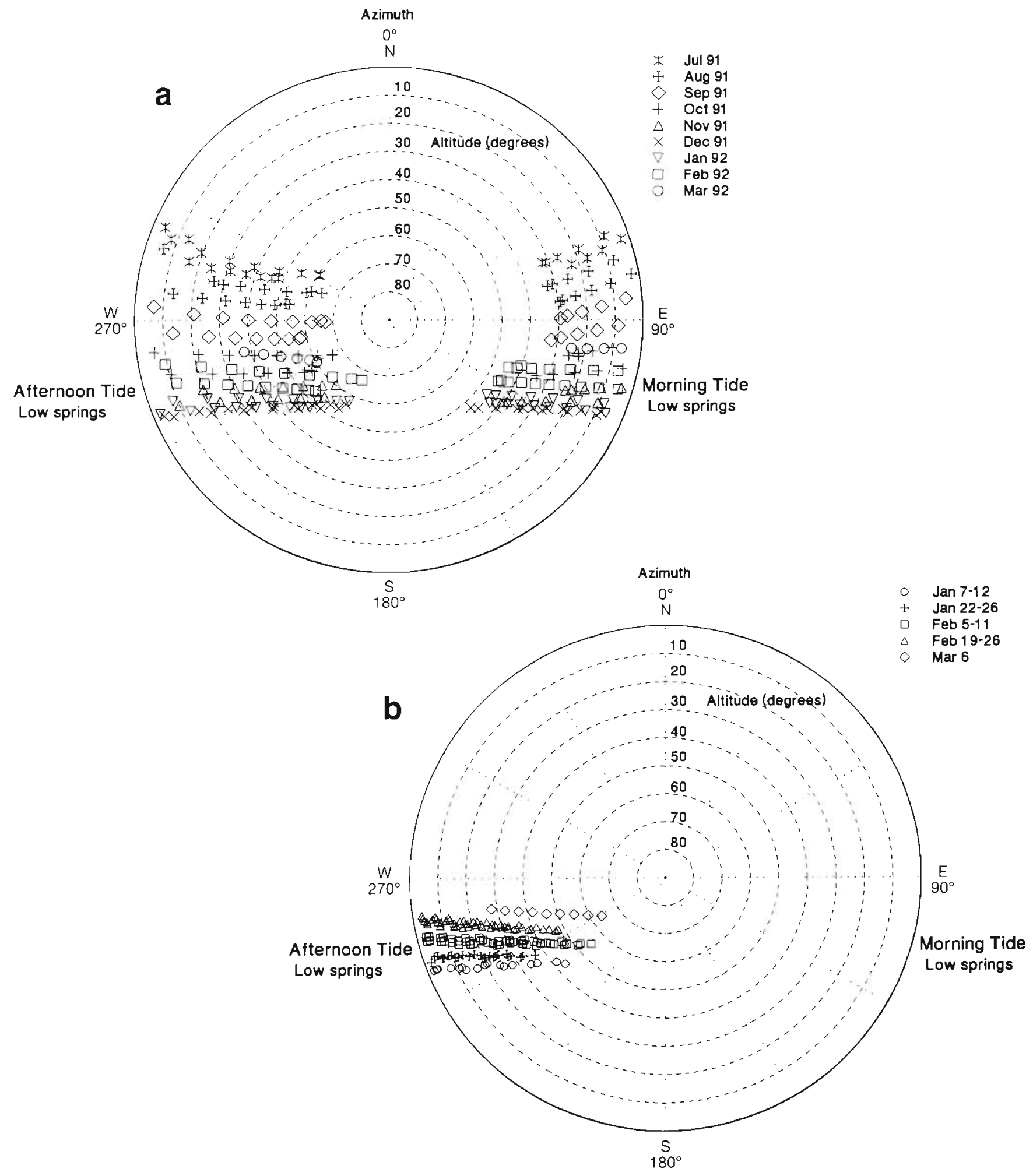

Fig. 6. Goniastrea aspera. (a) Polar plot of maximum sun altitude and corresponding azimuth during each daily period of spring low tide aerial exposure of inner reef-flat coral colonies at Site A between July 1991 and 8 March 1992. Maximum altitude on the morning tide is immediately prior to resubmergence and for the afternoon tides at time of onset of emergence. Each symbol marker represents 1 period of emergence (morning or afternoon). Each line of symbols coincides with a spring tide exposure period in Fig. 5a. (b) Polar plot of sun tracks (altitude and azimuth) for afternoon periods of subaerial exposure of coral colonies between the end of December 1992 and 7 March 1993. Sun tracks have been computed at 20 min intervals during each period of exposure. Symbols have been grouped into fortnightly periods of spring tides. Morning exposure is not shown 
lesions and the sun's position during the afternoon low spring tides. No solar lesion damage was recorded on the eastern half of colonies which are subject to direct solar irradiation during morning exposure.

Fig. 6a also shows that the maximum sun altitude for any period of morning exposure did not exceed $47^{\circ}$. The corresponding maximum altitude for the afternoon was $68^{\circ}$. The full sun track on any given day is represented by a line, originating in the case of the morning tide, or terminating for the afternoon, in the plot circumference $\left(0^{\circ}\right)$, and rising to or falling from the plotted maximum. Each set of monthly data form 2 lines of successive day maxima because of the $14 \mathrm{~d}$ periodicity of the spring tide exposure periods and the daily shift in the time of exposure.

In December 1992, of the 130 hemispherical colonies in the surveyed area at Site A, 87 had lesion scars and 43 were undamaged. During low spring tides in February 1993 (20 to 26 February) no new damage was present on these colonies. Immediately following the first afternoon of subaerial exposure on the next spring tides (6 March 1993) extensive fresh lesions were present. Of the 43 previously undamaged colonies, 31 bore new lesions, whilst the edges of all previous lesion scars also showed a narrow ring of newly bleached corallites. Colonies within the area were assigned to one of 3 groups; those with old lesion scars; previously undamaged with fresh lesions; and undamaged colonies. Heights of these groups of corals differed significantly from each other (Mann Whitney $U$ tests, $p<0.001$ ) the relative median height of each population was $0,-3.9$ and $-7.5 \mathrm{~cm}$ respectively. In addition to this height difference it was also noted that the undamaged colonies were submerged for most of any spring low tide period. Upward growth of colonies between periods of annual maximum subaerial exposure would render successive new cycles of colonies susceptible to damage.

Examination of subaerial exposure and sun position between December 1992 and the timing of the new 1993 lesions shows a similar relationship to the 1992 analysis (Fig. 6b). In particular none of the afternoon suntracks prior to 6 March 1993 gave maximum altitudes above $55^{\circ}$. In contrast, sun altitude during subaerial exposure on 6 March commenced at $64.4^{\circ}$ and remained above $55^{\circ}$ for the first $40 \mathrm{~min}$ of exposure.

To test the hypothesis that the appearance of fresh lesions on 7 March 1993 was related to the position of the sun on the preceding afternoon exposure, a mean azimuth and altitude for the sun was computed and compared to the mean angle of the lesion centres. The analysis of the sun track and in situ observations for 6 March 1993 showed that the corals experienced an unbroken period of direct sunlight between their emergence at 14:05 $\mathrm{h}$ and resubmergence at 16:45 h,
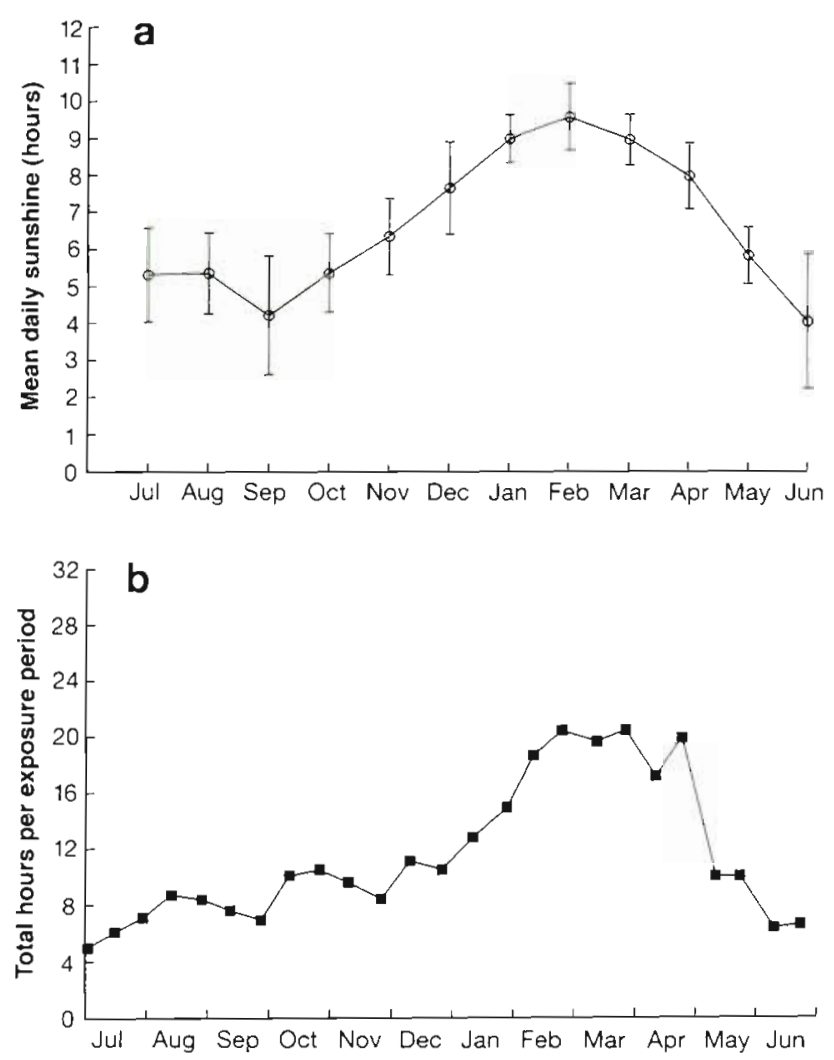

Fig. 7 Goniastrea aspera. (a) Mean daily hours of direct sunlight (unobscured by cloud) from 12 yr of data at Phuket Airport (1981 to 1992). Error bars represent standard deviations, $\mathrm{n}=12$. (b) Seasonal variation in direct sunlight hours experienced by coral colonies at Site A during periods of afternoon spring low tide emergence. Data points have been computed as a product of the length of aerial exposure (Fig. 5a) and seasonal variation in direct sunlight hours (Fig. 7 a). Direct sunlight hours were first 'normalised' for each month to a standard $12 \mathrm{~h}$ day by the relationship: [(recorded mean sunlight $) /($ mean day length $)] \times 12$

with altitude commencing at $64.4^{\circ}$ and decreasing to $26.9^{\circ}$, and azimuth between $239^{\circ}$ and $260^{\circ}$ (Fig. 6b); angular means were computed as $46^{\circ}$ and $252^{\circ}$ respectively. A V-test (Batschelet 1981, Zar 1984) for both bearing and elevation of the lesion centres rejected the null hypothesis of randomness $(\alpha=0.0001)$ in favour of the hypothesis that the lesion direction clustered around the mean sun altitude and azimuth.

Similar testing was applied to the lesions recorded at Site A on 8 March 1992. In this case an assumption was required, namely that, because of the fresh nature of the lesion damage, the cause of the lesions probably lay in the immediately preceding periods of afternoon subaerial exposure (1 to 7 March 1992) rather than in any previous period. For a mean sun azimuth of $256^{\circ}$ and altitude $31^{\circ}$ the $V$-test rejected randomness at $\alpha=$ 0.0001 
Analysis of the sunshine records from Phuket Airport show significantly higher daily mean values for the months of January, February and March in the hot dry NE monsoon than those for the remainder of the year (Fig. 7a) (Mann-Whitney, p < 0.02). When these data are adjusted for the slight variation in day length (maximum $12.6 \mathrm{~h}$ in June; minimum $11.67 \mathrm{~h}$ in January) and used to predict the probable hours of direct solar irradiation during the afternoon periods of subaerial exposure, the relationship in Fig. $7 \mathrm{~b}$ is obtained. The plot shows the period of highest solar radiation incident upon subaerially exposed corals to be during the months of February, March and April, complementing our field observations on the appearance of maximum lesions at this time of year.

\section{Solar irradiance measurements}

The broad band irradiance measurements showed that total solar irradiation on a surface horizontal with the reef flat during the afternoon period of subaerial exposure on 6 March was $27 \%$ higher than the next highest single exposure period (6 February) between December 1992 and March 1993 (Table 2). Spectroradiometer scans show that under clear sky conditions a 'horizontal' surface receives almost identical levels of short wavelength UVR ( 280 to $320 \mathrm{~nm}$ ) in the afternoon as the 'inclined irradiated' surface for solar altitudes of $65^{\circ}$ or less (Fig. 8a). At longer wavelengths the 'irradiated' surface receives greater irradiation than the 'horizontal' surface (Fig. 8b, c), with a maximum difference of $22 \%$ in the photosynthetically active (PAR) range.

\section{Sea suriace temperature}

Monthly mean sea surface temperatures at Phuket show a seasonal trend with highest temperatures (29.5 $\pm 0.3^{\circ} \mathrm{C}$ ) occurring during April and May at the end of the hot NE monsoon. Before and after the time that solar lesions appeared in 1993 (6 March) tempera-

Table 2. Solar irradiation $\left(\mathrm{kJ} \mathrm{m}^{-2}\right)$ on a horizontal surface at Phuket, Thailand, during periods of afternoon subaerial exposure. Spectral wavebands are for a $>50 \%$ response by sensors. Because of sensor response characteristics, values are comparative, not absolute

\begin{tabular}{|lcc|}
\hline Waveband & 6 Mar 1993 & 6 Feb 1993 \\
\hline $303-328 \mathrm{~nm}$ & 42 & 33 \\
$352-383 \mathrm{~nm}$ & 97 & 83 \\
$415-1000 \mathrm{~nm}$ & 4698 & 3794 \\
$350-2500 \mathrm{~nm}$ & 6270 & 4926 \\
\hline
\end{tabular}
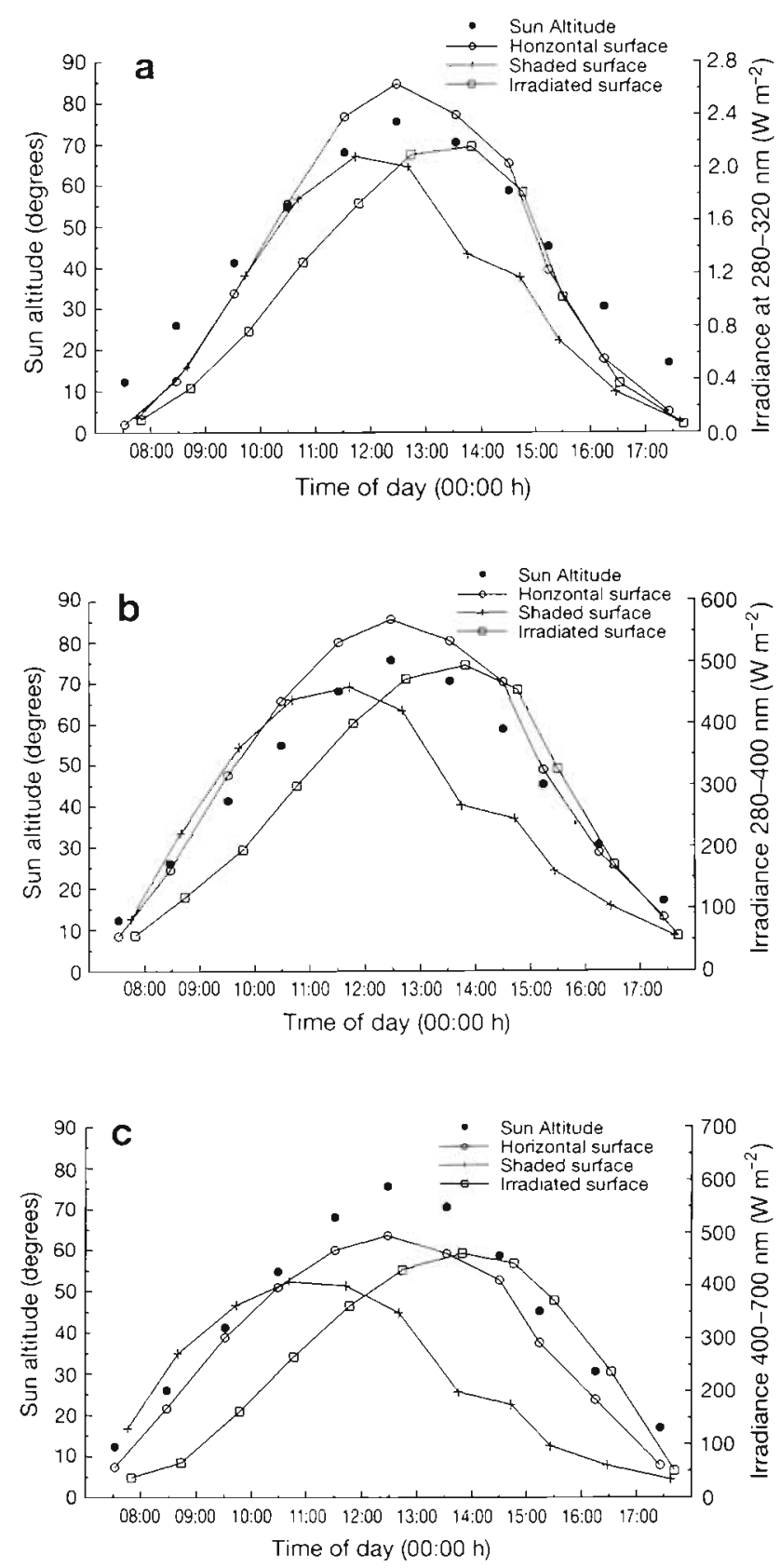

Fig. 8. Irradiance levels for typical clear sky conditions (4 March 1993) at Phuket Marine Biological Centre. (a) Short wavelength ultraviolet (UVR) irradiance between 280 and $320 \mathrm{~nm}$. (b) Total UVR irradiance 280 to $400 \mathrm{~nm}$. (c) Photosynthetically Active Radiation (PAR) irradiance 400 to $700 \mathrm{~nm}$. Irradiance is in units of $\mathrm{W} \mathrm{m}^{-2}\left(1 \mathrm{~W}=1 \mathrm{~J} \mathrm{~s}^{-1}\right)$

tures were normal for the time of year (MOHSST4 mean $29.1^{\circ} \mathrm{C}, \mathrm{PMBC}$ mean $28.6^{\circ} \mathrm{C}, 1951$ to 1980 GOSTA 'normal' $28.9 \pm 0.4^{\circ} \mathrm{C}$ ). Analysis of the continuous record between 25 February and 11 March 1993 from the thermistor at $0.5 \mathrm{~m}$ below chart datum gives a mean temperature of $28.9^{\circ} \mathrm{C}$, with a maximum of 
$29.7^{\circ} \mathrm{C}$ and a minimum of $28.1^{\circ} \mathrm{C}$. Diurnal variation was up to $1.2^{\circ} \mathrm{C}$ with highest recorded temperatures at about 18:00 h daily.

\section{DISCUSSION}

In this study, the bleaching damage we have recorded for Goniastrea aspera was highly directional, both in compass bearing (235 to $280^{\circ}$ ) and elevation (30 to $64^{\circ}$ ) (Fig. 3). Phuket's position close to the equator $\left(7^{\circ} 50^{\prime} \mathrm{N}\right)$ results in a predominantly east-west oriented sun track lying between the sun's maximum northerly limit in July and southerly limit in December, and slightly biased towards the southern celestial hemisphere (Fig. 6a). This pattern suggests a possible correlation with the observed damage, but without distinction between west and east sides of the colonies. The absence of east-facing lesions is explained by the pattern of subaerial exposure, whereby periods of afternoon exposure are both longer than in the morning (Fig. 5a), and closer in their timing to the daily maximum sun altitude. As a result the east-facing sides of colonies are subjected to lower maximum sun altitudes $\left(47^{\circ}\right)$ and for shorter periods compared to the afternoon $\left(68^{\circ}\right)$ (Figs. 5 a \& 6a, b). Solar irradiance and irradiation on the east side are therefore much reduced, presumably below any damage threshold.

The seasonality of lesion formation, with the highest incidence in February/March, further implicates solar irradiance as a major factor eliciting bleaching. The significant seasonal depression in mean sea level in January to March compared to the other months in the year (Mann-Whitney, $p<0.003$ ), coupled with maximum sun hours in the relatively cloudless months of January to March, at a time when the sun is almost directly overhead, act in concert with the timing of spring low tides to expose the corals to highest sun altitudes and greatest irradiance in late February and March each year. Any pattern between years will depend upon the precise timing of exposure (predominantly a tidal function) and annual variations in cloudiness. Thus, in March 1993 after the initial appearance of lesions, a few days of unusually overcast skies lead to partial remission in the initial severity of the bleaching damage.

Evidence of the directional nature of the stressor/s is also demonstrated by the correlation between lesion size and colony surface area, so that as the colony increases in diameter a greater area becomes susceptible to the directional effect (Fig. 4). Further support for solar irradiance as this directional stressor is demonstrated by observations on the fate of lesions. When cores of the lesions were removed from 3 damaged corals and transferred to running sea water aquaria and maintained for several days under natural diffuse light, but protected from direct solar radiation, the polyps remained viable and within $3 \mathrm{~d}$ regained their natural colouration, indicating a recovery of their zooxanthellae/pigment content. Similarly, reorientation of corals with solar lesions in the field through a compass angle of $180^{\circ}$ in early March 1992 resulted in rapid recovery of colour in formerly bleached areas (now facing the east) within $10 \mathrm{~d}$ of manipulation, whilst the majority of colonies left in place in March 1993 showed tissue necrosis in the fresh lesions within 2 to $3 \mathrm{~d}$. These manipulations and the observations on the progress of lesions suggest that the cause has a cumulative, as well as an acute, component

The dramatic appearance of the lesions in March 1993 immediately following the first low spring tide suggest that the loss/destruction of zooxanthellae/pigment is rapid, occurring in a matter of hours following the stress. Whilst the trigger was undoubtedly the higher irradiation recorded for that low tide period ( $27 \%$ greater than during previous exposure) we cannot rule out synergistic effects of other potential stressors, such as sea surface temperature. We consider, however, that any contribution from sea surface temperature as an omnidirectional, but nonetheless potential synergistic, stress is highly unlikely. The records of sea surface temperature show that at the time of the formation of new lesions in March 1993 the mean SST was normal for the time of year, and indeed $0.4^{\circ} \mathrm{C}$ below the highest seasonal means which occur annually in April and May. Similarly, the diurnal change in seawater temperature of $1.2^{\circ} \mathrm{C}$ (daytime warming / night time cooling) is consistent with records from December 1992, and April to June 1993

We have also considered other possible cause/effect relationships which could give rise to directional bleaching and/or mortality, such as wind/wave direction, or directional water flow during tidal cycles (Scoffin \& Stoddart 1978), but we are able to discount these alternative factors from our observations of similar lesion formation and directional growth morphology at the sites on differently oriented coasts. Additionally we have considered any role which disease might have played in lesion formation or propagation, but whilst histological examination of bleached polyps from corals at Site A in March 1992 showed reduced numbers of zooxanthellae, no characteristics associated with diseased tissues were present (Peters et al. 1983, Rutzler et al. 1983).

Our observations on solar effects, and directional mortality in several species of intertidal massive corals at Phuket, and the strikingly asymmetrical growth form which results is by no means site specific or unique. Buskirk et al. (1981) in Vanuatu $\left(16^{\circ} \mathrm{S}\right)$ noted that on intertidal coral heads of Goniastrea retiformis 
the boundary between living and dead coral polyps formed a plane whose angle was oriented with respect to the average winter sun angle. They attributed this to either solar radiation, or desiccation caused by the sun during periods of daytime subaerial exposure, which only occurred during winter months.

Identifying the precise cause of the solar bleaching observed in the present study is likely to be complex. Solar irradiance has many potential targets and mechanisms (e.g. radiant energy heating, desiccation, wavelength-related photosystem damage, other wavelength-related cell/molecular damage). Our measurements of irradiance on differently oriented surfaces show no difference in short wavelength UVR (280 to $320 \mathrm{~nm}$ ) between the 'horizontal' and 'inclined irradiated' surfaces on a hemispherically shaped object. These empirical results concur with Schauberger (1990) whose work included a comprehensive short wavelength UVR irradiance profile on a hemispherical surface for a single sun altitude of $66^{\circ}$.

Our findings are also consistent with the theoretical physical effects of (1) differently angled surfaces with respect to an energy beam (Lambert's cosine law), (2) the orientation of the plane of the surface to the natural horizon, and (3) the wavelength-dependent atmospheric scattering of solar radiation $\left(\alpha^{1} / \lambda^{s}\right)$. These all determine that an 'inclined irradiated' surface will receive increased direct irradiance but reduced diffuse irradiance compared with a 'horizontal' surface during afternoon subaerial exposure. A.t the short wavelengths (UVR 280 to $320 \mathrm{~nm}$ ) our measurements illustrate that these 2 factors effectively cancel each other, whereas at longer wavelengths (PAR, 400 to $700 \mathrm{~nm}$ ) the increasing direct component relative to diffuse (approximately $5: 1$ ) results in the higher recorded irradiances on the 'inclined irradiated' surface. Since no lesion damage was ever observed on the top ("horizontal') surfaces of colonies, this implies that short wavelength UVR is unlikely to be a prime cause of the bleaching.

At longer wavelengths (PAR, 400 to $700 \mathrm{~nm}$ ) our measurements showed substantially higher irradiation during subaerial exposure on the 'inclined irradiated' surfaces of the colonies ( $22 \%$ greater) than on 'horizontal' surfaces. Damage at these wavelengths could result from either radiant heating, desiccation, or photochemical damage or from a combination of these factors. There is increasing evidence that high levels of PAR affect algal photosynthetic systems, causing photoinhibition and subsequently photoxidation at elevated doses or over prolonged periods of time (see Powles 1984 for review). While photoinhibition has not been reported for any corals in situ, it is clear that high irradiances alone may have potentially damaging effects upon coral reef anthozoans (Muller-Parker
1984). When high irradiance is combined with increased temperatures (Coles \& Jokiel 1978, Lesser et al. 1990) and short wavelength UVR (Lesser et al. 1990) then these damaging effects may become exacerbated.

We conclude that the primary factor responsible for localised bleaching described in this paper was solar irradiance. While we are unable to attribute the bleaching response to a specific component of the solar radiation, our findings do not support a major role for UVR as a damaging influence. The possibility of significant effects of high PAR, desiccation, and heating remain, either alone or interactively, and are the subject of continuing study.

Acknowledgements. We thank the Director and Staff at the Phuket Marine Biological Centre, and in particular Dr Hansa Chansang and Mr Niphon Phongsuang, for their long-term support of the coral monitoring; Dr Bernard Yallop of the Royal Greenwich Observatory for a sun altitude/azimuth plotting program; Dr Robert W. Buddemeier for his careful and critical evaluation of various earlier versions of manuscripts; and Dr Brian Diffey for offering his considerable knowledge of ultraviolet radiation. This work and the continuing study is supported by a grant from the Overseas Development Administration's Natural Resources and Environment Department.

\section{LITERATURE CITED}

Batschelet, E. (1981). Circular statistics in biology. Academic Press, London

Brown, B. E., Ogden, J. C. (1993). Coral bleaching. Scient. Amer. 268: 64-70

Brown, B. E., Holley, M. C. (1982). Metal levels associated with tin dredging and smelting and their effect upon intertidal reef flats at Ko Phuket, Thailand. Coral Reefs 1: $131-137$

Brown, B. E., Le Tissier, M. D. A., Scoffin, T. P., Tudhope, A. W. (1990). Evaluation of the environmental impact of dredging on intertidal coral reefs at Ko Phuket, Thailand using ecological and physiological parameters. Mar. Ecol. Prog. Ser. 65: 273-281

Brown, B. E., Le Tissier, M. D. A., Dunne, R. P., Scoffin, T P. (1993). Natural and anthropogenic disturbances on intertidal reefs of S. E. Phuket, Thailand 1979-1992. In: Ginsburg, R. N. (ed.) Proceedings of the meeting on global aspects of coral reefs: health, hazards, and history. Rosenstiel School of Marine and Atmospheric Science, University of Miami, Coral Gables, p. J1-J7

Buskirk, R. E., Taylor, F. W., O'Brien, W. P., Maillet, P., Gilpin, L. (1981). Seasonal growth patterns and mortality of corals in the New Hebrides (Vanuatu). Proc. 4th int. coral Reef Symp. Manila 2: 197-200

Coles, S. L., Jokiel, P. L. (1978). Synergistic effects of temperature, salinity and light on the hermatypic coral Montipora verrucosa. Mar. Biol. 49: 187-195

Ditlev, H. (1978). Zonation of corals (Scleractinia: Coelenterata) on intertidal reef flats at Ko Phuket, Eastern Indian Ocean. Mar. Biol. 47: 29-39

Dunne, R. P. (in press). Ultraviolet radiation and coral bleaching. Nature

Fisk, D. A., Done, T J. (1985). Taxonomic and bathymetric patterns of bleaching in corals, Myrmidon Reef (Queensland). Proc. 5th int. coral Reef Symp. Tahiti 6: 149-154 
Fry, J. C. (1993). Biological data analysis. Oxford University Press, Oxford

Gleason, D. F., Wellington, G. M. (1993). Ultraviolet radiation. and coral bleaching. Nature. 365: 836-838

Glynn, P. W. (1984). Widespread coral mortality and the 1982/83 El Nino warming event. Environ. Conserv. 11: $133-146$

Glynn, P. W. (1991) Coral reef bleaching in the 1980 s and possible connections with global warming. Trends Ecol. Evol. 6: $175-179$

Glynn, P. W. (1993). Coral reef bleaching: ecological perspectives. Coral Reefs 12:1-17

GOSTA (1990). Global Ocean Surface Temperature Atlas. Meterological Office, Bracknell, UK, and Dept of Earth, Atmospheric and Planetary Sciences, Massachusetts Institute of Technology, Boston

Green, C. F., Deuchar, C. N. (1985). On improved tube solarimeter construction. J. exp. Bot. 36 (165): 690-693

Harriott, V. J. (1985). Mortality rates of scleractinian corals before and during a mass bleaching event. Mar. Ecol. Prog. Ser. 21: 81-88

Hoegh-Guldberg, O., Smith, G. J. (1989). The effects of sudden changes in temperature, light and salinity on the population density and export of zooxanthellae from the reef corals Stylophora pistillata Esper and Seriatopora hystrix Dana. J. exp. mar. Biol. Ecol. 129: 279-303

Kinzie, R. A. III (1993). Effects of ambient levels of solar ultraviolet radiation on zooxanthellae and photosynthesis in the reef coral Montipora verrucosa. Mar. Biol. 116: 319-327

Lesser, M. P. (1989). Photobiology of natural populations of zooxanthellae from the sea anemone Aiptasia pallida: assessment of the host's role in protection against ultraviolet radiation. Cytometry 10:653-658

Lesser, M. P., Shick, J. M. (1989). Effects of irradiance and ultraviolet radiation on photoadaptation in the zooxanthellae of Aiptasia pallida: primary production, photoinhibition, and enzymatic defenses against oxygen toxicity. Mar. Biol. 102: 243-255

Lesser, M. P., Stochaj, W. R., Tapley, D. W., Shick, J. M. (1990). Bleaching in coral reef anthozoans: effects of irradiance,

This article was submitted to the editor ultraviolet radiation, and temperature on the activities of protective enzymes against active oxygen. Coral Reefs 8 : $225-232$

Mardia, K. V. (1972). Statistics of directional data. Academic Press, London

Muller-Parker, G. (1984). Photosynthesis-irradiance responses and photosynthetic periodicity in the sea anemone Aiptasia pallida and its zooxanthellae. Mar. Biol. 92: $225-232$

Peters, E. C., Oprandy, J. J., Yevich, P. P. (1983). Possible causal agent of 'white band disease' in Caribbean acroporid corals. J. Invertbr. Pathol. 41: 394-396

Powles, S. B. (1984). Photoinhibition of photosynthesis induced by visible light. A. Rev. Plant Physiol. 35: 15-44

Rutzler, K., Santany, D., Antonius, A. (1983). The blackband disease of Atlantic reef corals. I: Description of a cyanophyte pathogen. P.S.Z.N. I: Mar. Ecol. 4: 301-319

Schauberger, G. (1990). Model for the global irradiance of the solar biologically-effective ultraviolet radiation on inclined surfaces. Photochem. Photobiol. 52: 1029-1032

Scoffin, T P., Stoddart, D. R. (1978). The nature and significance of microatolls. Phil. Trans. R. Soc. Lond. Ser. B 284: $99-122$

Scoffin, T P., Tudhope, A. W., Brown, B. E., Chansang, H., Cheeney, R. F. (1992). Patterns and possible environmental controls of skeletogenesis of Porites lutea, South Thailand. Coral Reefs 11: 1-11

Siebeck, O. (1988). Experimental investigation of UV tolerance in hermatypic corals (Scleractinia). Mar. Ecol. Prog. Ser. 43: 95-103

Szeicz, G., Monteith, J. L., Dos Santos, J. M. (1964). Tube solarimeter to measure radiation among plants. J. appl. Ecol. 1: 169-174

Vareschi, E., Fricke, H. (1986). Light responses of a scleractinian coral (Plerogyra sinuosa). Mar. Biol. 90: 395-402

Williams, E. H. Jr, Bunkley-Williams, L. (1990). The worldwide coral reef bleaching cycle and related sources of coral mortality. Atoll Res. Bull. 335: 1-71

Zar, J. H. (1984). Biostatistical analysis. Prentice-Hall, Englewood Cliffs, NJ

Manuscript first received: August 17, 1993

Revised version accepted: December 17, 1993 


\section{Erratum}

Re: B. E. Brown, R. P. Dunne, T. P. Scoffin, M. D. A. Le Tissier

Mar. Ecol. Prog. Ser. 105: 219-230 (1994)

- In Fig. 8 b on p. 227, the right hand $y$-axis scale should read 0 to 60 and not 0 to 600 as printed. The corrected figure is shown here.

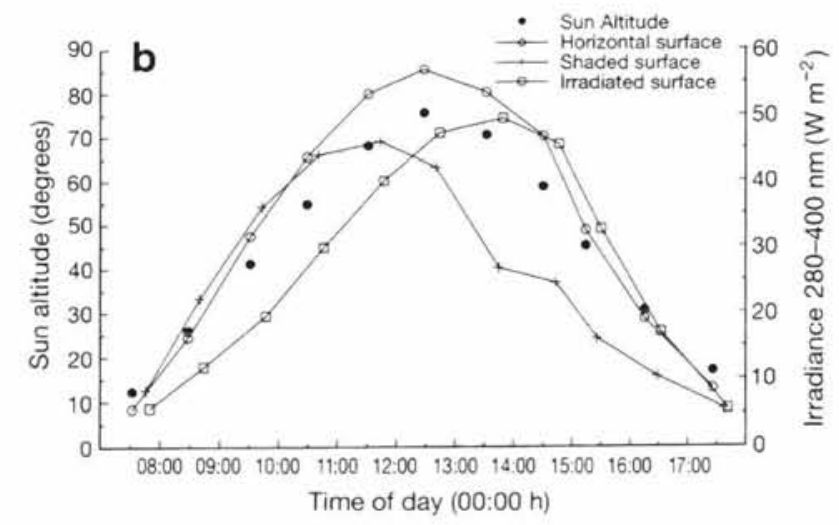

